\title{
E Pluribus Unum? The Communitarization of EU Migration, Asylum and Border Management Policies in Times of Crisis
}

\section{Tommaso Emiliani}

Senior Academic Assistant at the Department of EU International Studies \& Diplomacy, College of Europe, Dijver 11, 800 Bruges, Belgium

\section{crossef http://dx.doi.org/10.5755/j01.eis.0.11.18956}

The article accounts for the emergence of an external dimension of EU internal policies and focuses on the migration, asylum and border management domains. Building on Bretherton \& Vogler (2006), it assesses and explains the forms and extent of EU's external engagement. Firstly, it assesses the degree of EU actorness that is, the extent to which the Union has become an actor in global politics - in the researched fields in terms of opportunity, presence and capabilities. Secondly, it attempts to explain the emergence of such EU external engagement. While the article defends that the treaty objective of creating an European Area of Freedom, Security and Justice (article 3 TEU) makes EU external action in the migration, asylum and border control domains necessary, it also acknowledges the role of external triggers, such as the so-called 2015 'migration and refugee crisis'. On the one hand, external events can provide scope conditions accelerating the pace by which EU external action is pursued. On the other hand, they can also trigger the comeback of hard security concerns linked to claims for 'more national sovereignty', thus constraining the development of EU (external) action. The analysis carried out shows that the degree of EU actorness varies considerably across the three domains researched. On one extreme of the continuum, neo-realist understandings of increased arrivals of foreign citizens as hard security challenges to member states account for the enhanced interest in cooperation at the intergovernmental level. Such interpretations explain why the most established domain for EU external engagement is the cooperation with third countries on border management, as it is shown by the expansion of the mandate of EU agencies such as Europol and Frontex, or by negotiation by the European Commission of international agreements containing clauses on readmission of third country citizens irregularly residing in the EU to their countries of origin (the Mobility Partnerships).

Less developed, yet quickly evolving, is the EU external dimension of migration policies. Functional concerns related to the need to acquire highly specialized (and relatively cheap) workforce towards an efficient functioning of the single market have prompted a remarkable the law-making in this area, as shown by the EC directives and regulations aimed at third country students, unpaid trainees, voluntary workers and big corporations' staff. While the neo-functionalist logic explains the emergence of the external dimension of EU migration policies, it may also explain this development is currently limited to certain areas within the policy area. A comprehensive approach to migration policy has not proved possible to achieve so far, due to institutional and bureaucratic limitations, as well as the different agenda of national policymakers.

On the other extreme of the continuum, liberal theories and constructivism account for the constraints

\section{Abstract}

\section{ktu}

European Integration Studies No. $11 / 2017$

pp. 19-30

DOI 10.5755/j01.eis.0.11.18956 (c) Kaunas University of Technology 
currently limiting the full development of EU actorness in asylum policies. Several member states' civil societies do not perceive prospects for absolute gains deriving from cooperation at the EU level. Constraints to the establishment of international institutions regulating asylum policies are thus understood through the lack of strong societal pressures at the member states level.

Therefore, while the article puts forward a combination of neo-functionalist, neo-realist, liberal intergovernamentalist and constructivist explanations to account for the emergence of an external dimension of migration asylum and border management policies, as wells as for the obstacles opposing that process, it also provides evidence that external triggers such as increased migratory pressure lead to internal policy dynamics with positive or negative impacts on the shift of actorness from EU member states to the EU itself.

KEYWORDS: EU external engagement, EU migration policy, EU asylum policy, EU border management policy, External dimension, EU actorness.

\section{Introduction}

\section{Reaching out to the External Environment to Achieve EU Internal Aims}

The integration of the Area of Freedom, Security and Justice (AFSJ) as a substantial policy domain of the European Union (EU) is an on-going process. Although migration, asylum and border management policies - long considered core competences of states - already became EU shared competences with the Maastricht Treaty, full incorporation of these competences areas into EU policies has only happened gradually'.

Article 3(2) of the Treaty on the European Union (TEU) the creation of an AFSJ without internal frontiers, in which the free movement of persons is ensured in conjunction with appropriate measures with respect to external border controls, asylum, immigration and the prevention and combating of crime. Against the background of an increasingly interdependent world, and taken into account the intrinsically international nature of challenges such as migration, asylum seeking and border crossing, the treaty objective is hardly achievable through purely internal EU policies. Therefore, the development of an external dimension aimed at engaging third countries in the realization of EU internal aims is to be understood as directly related to the project of an internal AFSJ (Monar 2012: 11).

Standing the difficulties to advance a coherent EU policy in this field, it has to be noted the momentum provided for the establishment of truly European migration, asylum and border management policies by the occurrence of a set of events originating outside the EU borders. This article contends that external triggers, such as the so-called 2014-15 'migrant and refugee crises', provide scope conditions affecting the way in which and the pace by which EU external action is pursued. As such, the internal and external drivers may well have a mutual impact on EU actorness and external engagement.

The article has two key objectives: first, it aims to understand the development of the external dimension of EU migration, asylum and border management policies through an assessment of the degree of EU actorness in the three fields. To this end, it analyses the extent of the EU's external engagement with third countries, and the forms it assumes with regard to achieving the objective set down by Article 67 of the Treaty on the Functioning of the European Union (TFEU), namely the establishment of a EU common policy on asylum, immigration and external border control.

1 This article refers to EU migration policies as to EU rules regulating the inflow of third country economic migrants. EU asylum policies are understood as the EU rules aimed at harmonizing procedures for asylum applications and protection granted by the refugee status. for asylum of third-country nationals. EU border management policies are understood as the EU rules on external border crossings and the conditions governing the temporary reintroduction of internal border checks. The migration, asylum and border management domains are peculiar exceptions in the EU system, as policies do not apply by default to all EU member states. The United Kingdom and Ireland possess 'opt outs' provisions in these fields and are therefore exempted from applying relevant EU rules, unless they decide to 'opt in' on a case-by-case basis. Denmark refused the scheme altogether, and could theoretically join in only by accepting the full package of measures. 
Second, the article provides an explanation for the emergence and evolution of EU actorness. Although EU external engagement in the analysed areas is an emerging process and there is barely any single explanatory factor that can be identified as the main driver, I argue that, at a time when the stability of European borders is physically challenged by remarkable migratory flows, borders between EU domestic and external action with regard to migration management become increasingly fuzzy.

This section tracks the evolution of EU external engagement in migration, asylum and border management policies. It addresses the questions of how and to what extent the EU has achieved actorness in the observed domains. In doing so, it builds on the theoretical framework developed by Bretherton and Vogler (2006), which defines actorness in terms of opportunity, presence and capability.

\section{Opportunity: the external context}

Opportunity is understood as 'the external policy context' (Bretherton \& Vogler 2006: 24) of the migration, asylum and border management domains, e.g. the global institutional setting, that is the existence of an international governance architecture, and the global interest and norms constellation.

Regarding the global institutional setting, the competence to regulate movements of people across national borders has long been considered as a core component of sovereignty and as an exclusive prerogative of sovereign states (Anderson 1996). It is not surprising, therefore, to observe the absence of well-established multilateral frameworks in the three policy areas researched.

Since the 2000s, however, the international arena witnessed the quick development of a "bottom-up' global migration governance framework, which has been labelled 'substance without architecture' (Aleinikoff 2003: 467). Discussion fora and focus groups have been created to addresses the challenges related to migration and asylum law, mostly leaving border management policies up to states. The most recent initiative in this sense is the New York Declaration, issued by the UN General Assembly on September 2016. The document seeks the establishment of a Comprehensive Refugee Response framework, apt to implement more systematic and sustainable action benefitting both refugees and their hosts. Furthermore, the New York Declaration sets up the UN commitment to adopt a Global Refugee Compact in 2018, with the goals of easing pressures on host countries, enhancing refugee self-reliance, expanding third-country solutions and supporting conditions in countries of origin for return (UN 2016:3).

Concerning the global interest and norms constellations, migratory flows contribute to shaping the external environment and may produce incentives for policy-making. The so-called 'migrant and refugee crisis' the EU has been struggling with since 2014 provides an emblematic example. Increased arrivals of non-EU citizens seeking refuge and political asylum have called into question shared understandings of acceptable behaviour - that is, international norms - and led to a greater divergence of interests among the involved actors in the region, including the EU, Turkey and Russia.

While these actors seem to share a hard security interest in curbing irregular migrants' inflows in order to minimize perceived threats to their internal security and welfare systems, understandings of international obligations regarding asylum seekers largely differ across the area. On the one hand, the EU defends the abstract right of every individual fleeing persecution to apply for asylum in a member state. On the other hand, the EU has so far been hosting only a small fraction of displaced people from on-going conflict scenarios, while the other regional actors such as Jordan, Lebanon, Iraq and Turkey have been considerably higher amounts of migrants without, however, granting formal refugee status (Emiliani 2016).

The varied constellations of interests and ideas among sending, transit and receiving countries and the EU has led to 'multi-layered approaches to migration management' (Betts 2008). The

\section{Assessing the components of EU actorness}


most successful ones have led to the creation of regional migration regimes, addressing shared concerns and interests related to the mobility of workers and people as an integral part of common market-building, as in the case of the Latin American Southern Common Market (MERCOSUR) and the Economic Community of West African States (ECOWAS).

\section{Presence: the EU's acquis in migration, asylum and border management}

Defined as the 'ability of the EU to exert influence externally' (Bretherton \& Vogler 2006: 27), EU presence includes an assessment of what the EU stands for in a given domain, expressed in its legal and political acquis in this policy field.

While the Lisbon Treaty increased EU shared competence in migration, asylum and border management policies, law-making in these three areas is still not fully harmonize at EU level. For instance, the principle of subsidiarity, which allows the EU to act only when the policy goal can best be achieved at the Union level, still allows EU member states to retain a strong grip on the regulation of migration policies (Monar 2012: 25).

The EU's current approach on legal migration 'consists in adopting sectorial legislation by category of migrant' (Chateau 2016: 3). The EU has showed quite some remarkable agency law making with regard to legal immigration of third country citizens, as it is proved by the several directives issued on the right to reunification of regular migrants' family members (2003/86/EC), immigration of highly skilled workers (2009/50/EC), employment of seasonal workers (2014/36/EU), intra-corporate transfers of employees (2014/66/EU), entry and residence of third-country nationals for the purposes of research, studies, training, voluntary service and au pairing (2016/801/EU). As regards irregular migration, EU legislation regulates the return of irregular migrants to their countries of origin or transit in the 'Return Directive' (2008/115/EC) and introduced sanctions against employers who infringe the prohibition on employing illegally staying third-country nationals.

The situation is very different with regard of EU asylum policies, as no common EU asylum system has so far been achieved. Current legislation is limited to setting minimum standards for asylum seekers (Sy 2016). ${ }^{2}$ Council Directive 2005/85/EC on minimum standards on procedures in member states for granting and withdrawing refugee status lays down the rules regarding 'safe third countries' (e.g. not eligible for asylum), which are then decided upon based on national law and procedures in each member state. The EU also sets up the general system of distribution of asylum applications, establishing that asylum seekers should apply for asylum in the EU member state of first arrival (Dublin II Regulation). More recently, the Treaty of Lisbon has introduced a uniform asylum and subsidiary protection status (Article 78(2) TFEU). Despite the reforms undertaken with the recast of the Dublin system (European Commission 2017) the current system has proved insufficient to face the challenges brought about by the increased amounts of requests for asylum submitted to several EU countries since 2015.

The management of the EU's external borders is the area in which the EU has taken the most evident measures. Since the establishment of the Schengen system, the development of a joint management of the EU's external borders has become a priority of the concerned EU member states. TFEU codified the already existing political objective of introducing an integrated external border management system (Article $77(1)$ ). In terms of management instruments, a set of centralized databases for the purposes of migration and border management has been established, including the Schengen Information System (SIS), the Visa Information System (VIS) and an European database for information-sharing (Eurodac). Also, the EU has introduced a financial burden-sharing mechanism to support the countries at the external borders, the Internal Security Fund: Borders and Visa (2014-2020).

2 These rules are set out in the Directive on minimum standards on granting temporary protection (2001), Dublin II Regulation (2003), Directive on minimum standards for the reception of asylum-seekers (2003), Directive on minimum standards for the qualification of refugees (2004), Directive on minimum standards on asylum procedures (2004). 
The Commission has then proposed the establishment of an European Border and Coast Guard (EBCG) to react to the so called 'migrant and refugee crisis', with a 'right to intervene' when a member state is not able to cope with migratory pressure (Milt 2016: 3-4). Some commentators, such as the Slovak Prime Minister Robert Fico, have remarked the importance of the EBCG to "help us to get back to Schengen' (Politico 2016). The adoption of the legislative act establishing the EBCG took less than nine months which, according to the EU Commissioner Dimitris Avramopoulos, was a very quick development in comparison to the standard time of two years to pass EU legislation (Eder 2016), providing support to the view that the 'migrant and refugee crisis' accelerates the pace of further EU integration in migration, asylum and border management policies.

The European Agenda on Migration (European Commission 2015) constitutes the main policy framework for response to the migration challenges. While the Agenda does address the external dimension of migration and stresses the importance of cooperation with third countries, it does not make direct reference to the 2011 Global Approach to Migration and Mobility (GAMM), the current framework for EU external policy in the researched areas. In contrast to the GAMM, which does not explicitly mention the root causes of migration, the European Agenda on Migration seems to put a stronger focus on those underlying causes of migration and how those could be addressed in the long term (European Commission 2015a: 7).

\section{Capability: can the EU react to the external environment?}

Capability refers to those aspects of the EU policy process that constrain or enable external action (Bretherton \& Vogler 2006: 29). This subsection analyses EU competences for external activity, policy objectives, and procedures for external engagement.

The EU's capability to act externally depends on the institutional and legal development in a specific policy field. EU competence to act externally on migration, asylum and border management is explicitly defined in Articles 78(2) and 79(3) TFEU. Due to the shared competence, member states retain a partial competence since full harmonization has not taken place in most matters (Monar 2012:24).

With the Treaty of Lisbon, the EU has strived to develop a more coherent external policy and representation by codifying EU's capacity to sign readmission agreements with third countries (Article 79(3) TFEU) and to manage flows of asylum seekers in cooperation and partnership with third countries (Article 78(2) TFEU).

However, even after the creation of the European External Action Service (EEAS), obstacles remain. Whereas the EEAS' role is to integrate migration into a more strategic Foreign Policy perspective, DG HOME is more focused on internal migration priorities, (García Andrade, P., Martín, I. 2015:91). Weinar (2011: 7) argues that a mix of budgetary and institutional constraints limits the development of a true external migration policy. For instance, the only financial instrument at EEAS disposal is the Partnership Instrument. The fund can finance migration related activities for strategic countries, but it is not solely dedicated to migration actions. Thus, funding for migration policies and instruments is divided among DG DEVCO, DG HOME, DG NEAR and the EEAS. Furthermore, member states have different agendas and follow different interests, which forces the EU to act rather as the broker and communicator of this standpoint, than as the one engaged in policy-shaping (Weinar 2011: 3).

As mentioned above, the current EU external policy framework is formulated under the GAMM. The GAMM aims to maximize the impact of migration and mobility on development (Chateau 2016: 2). The main instruments introduced by the GAMM are the Mobility Partnerships (MPs), that combine different policies tools, mainly linking the granting of legal channels of migration and mobility to the signature of readmission agreements. However, being 'soft policy instruments' (García Andrade, P., Martín, I. 2015: 30-34) negotiated by the European Commission on behalf of willing member states, MPs lack widespread backing at the EU level. 


\section{The extent and the forms of EU external engagement}

The analysis of the three components allows for an assessment of EU actorness on the three domains. Overall, opportunity seems conducive to emerging EU actorness in the migration and asylum policy fields, but only to constrained actorness in border management. The absence of an institutional, multilateral framework to address migration and asylum issues gives room to the $\mathrm{EU}$ to potentially fill in the role as the main regional institution.

The external pressure brought about by the so-called 'refugee crisis' seems to enhance the opportunity for EU action in the three domains analysed. As heightened migratory inflows are perceived by public opinions and policy makers across Europe as threats to the stability of EU and to the welfare systems of member states (De Geus et al. 2016), the EU has been claiming an increasingly stronger role to play. Evidence for such is provided by the entrepreneurship displayed by the Council in the signature of the so called 'EU-Turkey refugee deal', or by the rather assertive tone used by the Commission in key documents such as the 'European Agenda on Migration', that in its Introduction states:

'It is clear that we need a new, more European approach. This requires using all policies and tools at our disposal - combining internal and external policies to best effect. All actors: member states, EU institutions, International Organisations, civil society, local authorities and third countries need to work together to make a common European migration policy a reality.' (European Commission 2015).

The analysis of EU presence leads to similar findings, although the extent of EU actorness varies considerably across the three domains analyzed. EU external engagement appears rather weak in asylum policies, due to the lack of a harmonized framework to deal with the challenges brought about by increased inflows of asylum-seekers. The so-called 'Dublin system' (with its multiple recasts) has not proved sufficient to engage external actors in an efficient way. EU presence appears moderately developed in migration policies, thanks to framework strategies such as the European Agenda on Migration, that foresee operative measures to reach out to third countries and non-EU citizens. Finally, EU presence seems quite strong in the border management policy area, thanks to the creation of the EBCGA and the policy framework established by GAMM and in particular to the signature of MPs including agreements on readmission of third country nationals.

The capabilities of the EU in migration, asylum and border management external action are largely shaped by their nature as a shared competence of the Union. EU capability is rather developed when it comes to migration management. The EU has a clear mandate to enter into readmissions agreements (see Article 79(3) TFEU) with third countries and to tackle incentives to work irregularly on the EU market. Regular migration, however, is only regulated on a sectorial basis. This impacts also the capability to act externally for the EU's overall external migration policy, since some of the policy instruments such as MPs combine incentives such as regular migration with more coercive measures such as readmission agreements.

Asylum is the policy area where only minimum standards have been agreed upon at the EU level. The EU has been struggling to agree on quotas for distribution and a common system, as this is met with strong resistance from some member states. This, in turn, also limits EU external capability when it comes to negotiating agreements with third countries. For instance, the socalled 'EU-Turkey refugee deal' rests upon the EU promise to take in a refugee in return for each refugee who was sent back to Turkey. Since the EU cannot impose quotas on the member states, it has to rely on voluntary quotas, which are lower than the numbers needed to ensure that the EU can meet its obligations under the agreement.

As the graph below shows, in this analysis EU activities range from the mere (unintended) radiation of internal policies across borders, to an externalization of EU policies for the purpose of creating broader spaces in which EU rules apply, to the integration of EU (internal and/or external) 
policy objectives into other external policies than the one corresponding to the original internal policy, often referred to as mainstreaming, to the most developed form of external engagement that exists at present time only in theory: a full-fledged EU 'sectorial diplomacy'.

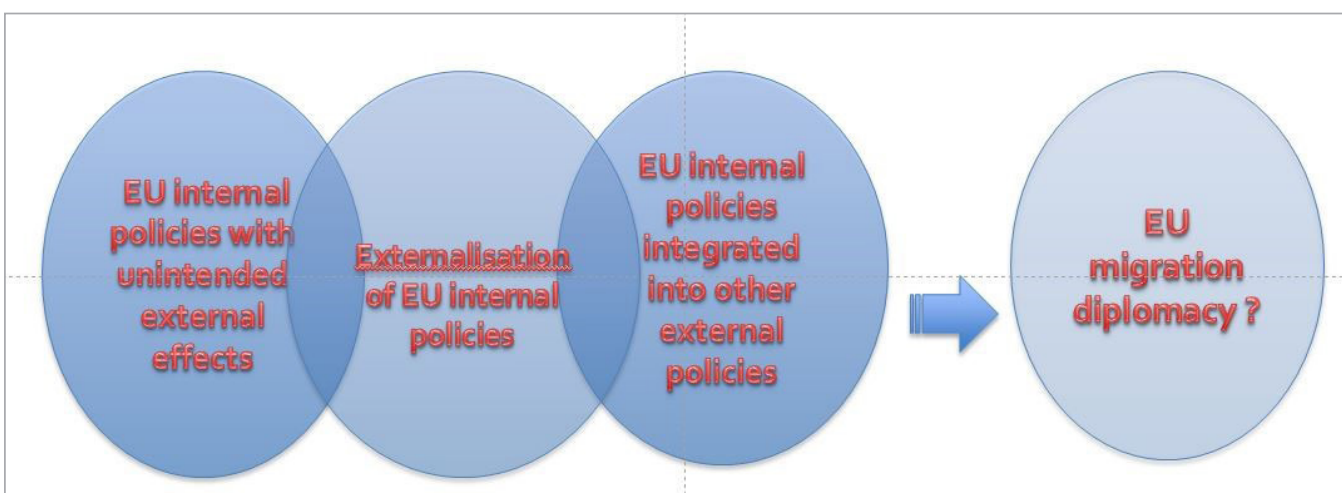

Forms of EU external engagement in migration, asylum and border management policies (Emiliani: 2017)

Currently, the externalisation of EU internal policies appears to be the most recurring form of EU external engagement.

With respect to migration policies, the GAMM seeks to institutionalize collaboration with third countries on a variety of migration-related issues. On the one hand, the document acknowledges EU labour market shortages due to member states' ageing population, as well as the need for qualified labour. On the other hand, it highlights that increased influxes of irregular migrants are likely to be successfully addressed only if a genuine cooperation with third countries is established, for instance through MPs aimed at facilitating legal migration for specialized workers from partner countries in exchange for a firm commitment to readmit irregular migrants found on EU member states' territory. The agency here lies with the Commission, which negotiates Mobility Partnerships on behalf of member states, while the latter retain the right to opt out of these agreements.

With regard to asylum policies, the EU engages in advocacy activities to promote adherence by third countries with EU values and provides humanitarian aid and capacity-building to third countries hosting considerable numbers of asylum-seekers, as well as resettlement schemes to share third countries' burden to host refugees. A telling example in this sense is the chapter on asylum included in the 2016 so called 'EU-Turkey refugee deal': the advocacy dimension is found in the EU request that Turkey - that is not part to the Geneva convention and is therefore not bound by international law on refugees - should grant Syrian asylum seekers a temporary protection status. The economic aid and solidarity dimensions are accounted for by the financial disbursement under the Facility for Refugees in Turkey instruments that will reach 6 billion euros transferred to Turkey in 2018 (European Commission 2017), as well as the relocation scheme put forward by the European Commission to resettle Syrian refugees from Turkey to EU member states.

Regarding border management policies, perceived challenges linked to the influx of refugees and migrants, as well as heightened security concerns, have triggered strong reactions and a shift towards more direct operational EU support to member states and collaboration with third countries. In this field, the EU relies on its ad hoc agencies to achieve treaty objectives. EBCG has so far signed 17 working arrangements with countries from all over the world focusing on the establishment of operational cooperation in several fields of action. The working agreement with 
Ukraine, for instance, sets out a structured dialogue on the operational cooperation in border-related matters that includes daily contacts via agreed points of contact and the establishment of expert working groups will be established with the objective to facilitate measures taken by Frontex and the State Border Guard Service of Ukraine (Frontex 2007). Frontex also takes part in other GAMM instruments such as Mobility Partnerships, CAMMs and migration dialogues.

Multiple reasons account for such shift from a purely internal dimension to external action. For what it concerns migration policies, the comprehensive approach promoted by the Commission and the Parliament within the EU needs the implementation of development policies aimed at curbing the need and desire of non-EU citizens to quit their countries of origin in the first place. These policies, while still aimed at the fulfilling the internal objective to reduce migration inflows to the EU, are designed to have an impact on third countries, and inherently require their cooperation. With regard to asylum policies, the EU has an interest in making its partners more accountable in order to make sure that less asylum claims are lodged legally in its member states. The so-called 'safe third country' and 'safe country of origin' lists, issued by the EU to reduce grounds for asylum claims by incoming migrants, are to be read through these lenses. The same logic applies to the advocacy activities undertaken by the EU vis-à-vis those countries that are not party to the Geneva Convention - like Turkey - with the goal of inducing them to grant a special protection status to asylum seekers. Finally, border management policies abide to what Lavenex has called the policy of 'shifting up and out', that is, to transfer a security-oriented approach to the protection of EU borders to third countries in order to evade the legal constraints that EU liberal democracies oppose to the rejection of unwanted migrants (Lavenex 2010: 332).

\section{Explaining the emergence of EU external engagement}

The emergence and evolution of EU external engagement in the three domains researched can be explained with reference to several key factors related to, first, the notions of EU opportunity at the international level and, second, the notion of EU capabilities and presence enabling or constraining the Union's external action ${ }^{3}$

\section{Multiple external crises as pulling factors for external engagement}

International crises such as the wars in Syria (2011-), Libya (2011-) and Donbass (2014-), as well as the political unrest brought about by the so-called Arab Spring (2011) and the change of environmental conditions affecting in particular the area of Sub-Saharian Africa had a strong impact on migratory flows of individuals towards the EU. From a neo-realist perspective, increased arrivals of foreign citizens pose a hard security challenge to member states that find an interest in cooperation at the intergovernmental level to protect their power. Such interpretation would explain why the most established domain for EU external engagement is the cooperation with third countries on border management. Members states have long been engaging in the externalisation of their border protection to third countries, as it is shown for instance by the bilateral deals struck in 2008 by French then-President Sarkozy and his Tunisian homologue Ben Ali (Mikail 2011: 4) or Italian then-Prime Minister Berlusconi and Lybian then-President Gheddafi (Camera dei Deputati 2009). The shift to the European arena is analysed by Lavenex in her seminal work on 'shifting up and out' responsibility for immigration control (Lavenex 2010) as a strategy for institutional proponents of a security-oriented approach to migration management in the member states to build common grounds for cooperation without compromising on national asylum and immigration systems. In other words, 'escape to Europe' for national executives, accounts for as an evidence of 'venue-shopping' (Guiraudon 2000) from a realist perspective, that is to say, the need to find a political arena less constrained by the legal and normative constraints present in EU liberal democracies' national arenas. Therefore, whereas internally the move towards

3 This section is built on the findings of Emiliani \& Linck (forthcoming). 
communitarization of policies is met with reluctance towards transfers of sovereignty, external intergovernmental cooperation is on the contrary understood as a tool to readdress national executives' control over borders. This would explain the entrepreneurial role taken by the Council in the negotiations over the so-called refugee deal with Turkey in March 2016.

Liberal theories and constructivism can, on the other hand, account for the constraints currently limiting the full development of an external dimension of EU migration and asylum policies. Neoliberal institutionalists would argue that constraints to the establishment of international institutions regulating asylum policies are explained through the lack of strong societal pressures aimed to that end at the member states level.

\section{Increased policy coherence as the pushing factor for external engagement}

At the EU level, the drive for a stronger external engagement is described by liberal intergovernamentalist theory with the EU strong bargaining power vis-à-vis third countries when compared to single member states. Proponents of this school of thought maintain that integration of national policies at the EU level (both at the internal and external level) happens insofar there is an aggregation of member states preferences and relative bargaining power on specific issues (Moravcsik 1993: 479). Evidences for EU migration policies can be found in the case of MPs, negotiated by the European Commission on the behalf of the interested member states.

Neo-functionalists argue that the development of an external dimension of EU immigration policies as a spill-over of the internal market and its four freedoms, the free movement of persons within its borders only being possible if external borders are effectively protected and if some basic common rules regulating the movement of third-country migrants are in place (Guiraudon 2000: 254). The need for EU external action has been further exacerbated with the entry into force of the Schengen in 1995, and the later integration of the Schengen acquis into the EU framework. While the neo-functionalist logic explains the emergence of the external dimension of EU immigration policies, it may also explain why EU migration policies remained limited to certain areas within the policy area, which were necessary to allow the single market to function. A comprehensive approach to migration policy was not possible due to institutional and bureaucratic limitations, as well as the different agenda of national policymakers. Many aspects of the broader migration agenda, such as access to the labour market for third world, social policies and regular economic migration for many categories of individuals are still under the exclusive competence of the EU member states (Weinar 2011: 2).

The last strand of theoretical explanations for EU external engagement relies on the constructivist conceptualisation of Europe-as-a-power, that is to say, the expansion of EU influence outside its borders by virtue of the values and norms intrinsically related to its presence. Thus, the notion of Market Power Europe (MPE), that tries to explain EU's external engagement by its attempt to externalise EU social and internal market-related regulatory policies, would interpret EU directives on third country nationals as a way to provide the Single Market with highly specialised workforce and the provisions on higher flexibility and mobility contained in the GAMM a legal tools to acquire cheap main oeuvre. Pushing this theorization to its limits, even the EU official 'inclusive' discourse on refugees, built on the support of large sectors of the European private sector, could be thus understood as a tactical move to provide cheap labour force to the internal market.

On the other end of the conceptualisation of the external engagement as an EU instrumental tactic lies the notion of Normative Power Europe (NPE). According to lan Manners, who developed the concept, the EU is defined on the international stage by the fundamental values inscribed in its founding treaties (Manners 2002: 252), that allow it to shape the identities and behaviours of the actors interacting with the Union. From a NPE perspective, then, the EU effort to uphold an international protection regime for refugees worldwide is the product of the influence the Union exercises beyond its borders by virtue of its commitment to human dignity, freedom and rule of law. 


\section{Towards the establishment of an 'EU migration diplomacy'?}

This article examined the impact of external events on EU's external engagement in the areas of migration, asylum and border management policies.

While the creation of an AFSJ was already foreseen in the 1992 Maastricht Treaty, EU's internal legal and policy acquis has long remained constrained with regard to migration, asylum and border management policies, so that key decision have been taken at the intergovernmental level until very recently. However, recent challenges brought about by increased inflows of third country nationals - and attached perceptions of threats to EU member states' reception systems- have contributed to the quick development of EU actorness in the researched domains.

The analysis carried out showed how the three policy domains researched, although closely interlinked, present distinct extents of actorness and produce different forms of EU external engagement. While external events such as the so-called 'migrant and refugee crisis' open up the window for an increased role of the EU as a global actor in devising an international asylum policy, its scarce legal capabilities sharply constrains its actorness.

With the inclusion of the goal of establishing a 'more effective migration policy' in the June 2016 Global Strategy for the EU's foreign and security policy (EEAS 2016: 28), it appears certain that the Union will increase in the next future its external engagement with third countries in the areas of migration, asylum and border management, so that the border between its internal and foreign policies will become even more fuzzy. Whether this process will be conductive to the establishment of a full-fledged sectorial diplomacy rests to be seen and depends on the possible occurrence of a combination of internal and external events.

First and more important, the reconciliation of the interests and tensions existing among the three domains. As long as Justice and Interior ministries who lead the externalization of border management will not take into account the humanitarian and development actors' stake in the establishment of an international asylum system, as well as the stakes of business private and institutional actors in a migration policy functional to the internal market, chances for an EU migration diplomacy will remain constrained (Emiliani 2016).

Second, the impact that political events happening worldwide will have on the Union. The analysis carried out in this article has highlighted how the so-called 'migrant and refugee' crisis that has been strikin Europe since 2015 has proved instrumental to the enhancement of the external dimension of EU border management policies. EU Migration and asylum policies, on the opposite, have been affected negatively by the crisis, marking a partial resurgence of nationalist claims at the member state level and intergovernmental decision-making at the EU level. However, other kinds of political crises are also likely to affect the way EU's immigration policy will evolve. The reaction of EU member states to the exit of the United Kingdom from the Union and to the Foreign Policy devised by the Trump administration in the U.S., with its tough stance on immigration and its commitment to withdraw from negotiations on a Trans-Atlantic Partnership treaty with the EU, will have existential consequences on EU migration, asylum and border management policies.

Will the EU rally around the flag in times of quick changes on the international political stage, or will member states attempt at making sense of the current transformations by advocating the return to national and local solution to global challenges? The question concerns as much the future of the EU migration, asylum and border management policies as that of the Union's itself.

\section{References}

Aleinikoff A. \& V. Chetail (eds) (2003) Migration and International Legal Norms, The Hague: Asser Press. https://doi.org/10.1007/978-90-6704-459-2

Anderson, M. (1996) Frontiers: Territory and State For- mation in the Modern World, Cambridge: Polity Press. Betts, A. (2008), 'Global Migration Governance', GEG Working Paper 2008/43, Oxford: University of Oxford. Bretherton, C. \& J. Vogler (2006), The European Union 
as a Global Actor, 2nd edn, London: Routledge.

Camera dei Deputati della Repubblica Italiana (2008), Trattato di amicizia, partenariato e cooperazione tra la Repubblica italiana e la Grande Giamahiria araba libica popolare socialista, fatto a Bengasi il 30 agosto 2008, Rome, 12 September.

Chateau, C. (2016), Immigration Policy, Fact Sheets on the European Union.

Council of the European Union (2003), Council Regulation (EC) No 343/2003 Establishing the Criteria and Mechanisms for Determining the Member State Responsible for Examining an Asylum Application Lodged in one of the Member States by a Third-Country National (Dublin II Regulation), Brussels, 18 February.

Council of the European Union (2004), Directive 2004/114/EC on the Conditions of Admission of Third-Country Nationals for the Purposes of Studies, Pupil Exchange, Unremunerated Training or Voluntary Service, Brussels, 13 December.

Council of the European Union (2005a), Council Directive 2005/85/EC on Minimum Standards on Procedures in Member States for Granting and Withdrawing Refugee Status, Brussels, 1 December, 12 October.

Council of the European Union (2005b), Directive 2005/71/EC on a Specific Procedure for Admitting Third-Country Nationals for the Purposes of Scientific Research, Brussels, 4 October.

Council of the European Union (2009a), The Stockholm Programme - An Open and Secure Europe Serving and Protecting the Citizens, 17024/09, Brussels, 2 December.

Council of the European Union (2009b), Council Conclusions on Policy Coherence for Development (PCD), 2974th External Relations Council meeting, Brussels, 17 November.

Council of the European Union (2009c), Directive 2009/50/EC on the Conditions of Entry and Residence of Third-Country Nationals for the Purposes of Highly Qualified Employment, Brussels, 25 May 2009.

Council of the European Union (2016a), Council Conclusions on External Aspects of Migration, 9111/16, Brussels, 13 April.

De Geus, A. et al. (2016), The Refugee Crisis: A European Call for Action, Brussels: Bruegel Institute, available at: http://bruegel.org/2016/03/the-refugee-crisis-a-european-call-for-action/.

Del Sarto, R. A. \& C. Steindler (2015), 'Uncertainties at the European Union's Southern Borders: Actors, Policies, and Legal Frameworks', European Security, 24(3), 369-380. https://doi.org/10.1080/0966283 9.2015.1028184

Emiliani, Tommaso (2016), "'Refugee Crisis" - "EU Crisis"? The Response to Inflows of Asylum-Seekers as a Battle for the European Soul', College of Europe Policy Brief series, Bruges: College of Europe.
Emiliani, T. \& Linck, Annika (forthcoming), "Reacting to External Events? The External Dimension of EU migration, Asylum and Border Management Policies", Routledge: London.

European Commission (2011), Communication from the Commission to the European Parliament, the Council, the European Economic and Social Committee and the Committee of the Regions: The Global Approach to Migration and Mobility, COM(2011) 743 final, Brussels, 18, November.

European Commission (2013), Communication from the Commission to the European Parliament, the Council, the European Economic and Social Committee and the Committee of the Regions: Maximising the Development Impact of Migration, COM(2013) 292 final, Brussels, 21 May.

European Commission (2014a), Shaping the Future of Home Affairs Policies - The Next Phase, Press Release, Strasbourg, available at: http://europa.eu/ rapid/press-release_IP-14-234_en.htm?locale=en, 11 March.

European Commission (2014b), Communication from the Commission to the European Parliament, the Council, the European Economic and Social Committee and the Committee of the Regions: An Open and Secure Europe: Making It Happen, COM(2014) 154 final, Brussels, 11 March.

European Commission (2015b), Communication from the Commission to the European Parliament, the Council, the European Economic and Social Committee and the Committee of the Regions: A European Agenda on Migration, COM(2015) 240 final, Brussels, 13 May.

European Commission (2016), Association Agreements/DCFTAs Georgia, the Republic of Moldova and Ukraine - Remarks by Johannes Hahn on behalf of the HR/VP at the EP, available at: http://europa.eu/rapid/ press-release_SPEECH-16-121_en.htm, 20 January.

European Commission (2016b), Communication from the Commission to the European Parliament, the Council, the European Economic and Social Committee and the Committee of the Regions on the State of Play of Implementation of the Priority Actions under the European Agenda on Migration, COM(2016) 85 final, Brussels, 10 February.

European External Action Service (2016), Shared Vision, Common Action: A Stronger Europe - A Global Strategy for the European Union's Foreign and Security Policy, Brussels, June.

European Parliament \& Council of the European Union (2008), Directive 2008/115/EC on Common Standards and Procedures in Member States for Returning Illegally Staying Third-Country Nationals, Brussels, 16 December.

European Parliament \& Council of the Europe- 
an Union (2011), Directive 2011/98/EU on a Single Application Procedure for a Single Permit for Third-Country Nationals to Reside and Work in the Territory of a Member State and on a Common Set of Rights for Third-Country Workers Legally Residing in a Member State, Brussels, 13 December.

European Parliament \& Council of the European Union (2014a), Directive 2014/36/EU on the Conditions of Entry and Stay of Third-Country Nationals for the Purpose of Employment as Seasonal Workers, Brussels, 26 February.

European Parliament \& Council of the European Union (2014b), Directive 2014/66/EU on the Conditions of Entry and Residence of Third-Country Nationals in the Framework of an Intra-Corporate Transfer, Brussels, 15 May.

European Parliament \& Council of the European Union (2015), Joint Communication Addressing the Refugee Crisis in Europe: The Role of EU External Action, JOIN(2015) 40 final, Brussels, 9 September.

European Parliament \& Council of the European Union (2016), Regulation 2016/1624 on the European Border and Coast Guard and amending Regulation (EU) 2016/399 of the European Parliament and of the Council and repealing Regulation (EC) No 863/2007 of the European Parliament and of the Council, Council Regulation (EC) No 2007/2004 and Council Decision 2005/267/EC, Brussels, 14 September.

European Union (1992), Treaty on European Union (Treaty of Maastricht), Maastricht, 7 February 1992.

Eder, F. (2016), New Border Force Guards Europe's 'Broken fence', Politico, available at: http://www. politico.eu/article/new-border-force-guards-europes-broken-fence-frontex-schengen-dimitris-avramopoulos/, 10 June.

Frontex (2007), Working Arrangement on the establishment of Operational Cooperation between the European Agency for the Management of Operational Cooperation at the External Borders of the Member States of the European Union (Frontex) and the Administration of the State Border Guard Service of Ukraine, Luxembourg, 5 December.
García Andrade, P. \& I. Martín, (2015), ‘EU Cooperation With Third Countries In The Field Of Migration', Policy Department Citizens' Rights and Constitutional Affairs, European Parliament, Brussels, October.

Guiraudon, V. (2000), 'European Integration and Migration Policy: Vertical Policy-making as Venue Shopping', Journal of Common Market Studies, Vol. 38, No. 2, pp. 251-71. https://doi.org/10.1111/14685965.00219

Lavenex, S. (2006), 'Shifting Up and Out: The Foreign Policy of the European Immigration Control', West European Politics, 29(2), 329-350. https://doi. org/10.1080/01402380500512684

Lavenex, S. \& N. Wichmann (2009), 'The External Governance of EU Internal Security', Journal of European Integration, 31(1), 83-102. https://doi. org/10.1080/07036330802503932

Monar, J. (2012), 'The External Dimension of the EU's Area of Freedom, Security and Justice - Progress, Potential and Limitations After the Treaty of Lisbon', SIEPS Working Paper 1, Stockholm: Swedish Institute for European Policy Studies.

Moravcsik, A. (1993), 'Preferences and Power in the European Community: A Liberal Intergovernamentalist Approach', Journal of Common Market Studies, 31(4), 473-524. https://doi. org/10.1111/j.1468-5965.1993.tb00477.x

Sy, S. (2017), Asylum Policy, Fact Sheet on European Union, available at http://www.europarl. europa.eu/atyourservice/en/displayFtu.html?ftuId=FTU_5.12.2.html, January.

United Nations (2016), Resolution Adopted by the General Assembly on 19 September 2016, 71/1. New York Declaration for Refugees and Migrants, New York, 22 September

Waltz, K. N. (1979), Theory of International Politics, New York: McGraw-Hill.

Weinar, A. (2011), 'EU Cooperation Challenges in External Migration Policy', Background Report for EU-US Immigration Systems (2011/02), San Domenico di Fiesole (FI): Robert Schumann Centre for Advanced Studies, European University Institute.

\section{About the author \\ TOMMASO EMILIANI \\ Senior Academic Assistant}

Department of EU International Studies \& Diplomacy, College of Europe

\section{Fields of research interests}

EU migration, asylum and border management policies, EU anti-radicalisation strategies; European Neighbourhood Policy; Middle East affairs; political sociology; international negotiation analysis

\section{Address}

Dijver 11, 800 Bruges, Belgium

E-mail: tommaso.emiliani@coleurope.eu 